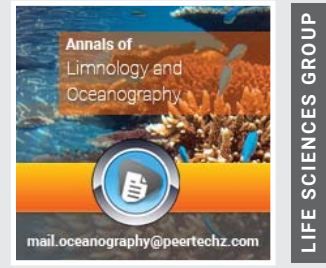

\title{
Analysis of physicochemical parameters of the Hebbal, Shivpura, Elemallappa Shetty Lakes in Bengaluru City, India
}

Received: 06 April, 2020

Accepted: 09 June, 2020

Published: 10 June, 2020

*Corresponding author: Aratrika Chatterjee, CHRIST (Deemed to be University), Bengaluru, Karnataka, India, E-mail: aratrikachatterjee19@gmail.com

Keywords: Physicochemical parameters; Seasonal variations; Statistical analysis

https://www.peertechz.com

\section{Check for updates}

\section{Aratrika Chatterjee ${ }^{1 *}$, Ganesh $\mathrm{S}^{2}$}

CHRIST (Deemed to be University), Bengaluru, Karnataka, India

\section{Abstract}

A comparative physicochemical study was done by collecting water from three lakes in Bengaluru City, India. Most of the collected water samples were observed to be within the prescribed limits suggested by World Health Organization and Indian Standard Institute for drinking purpose. Seasonal variations are seen in physical and chemical parameters like color, odour, $\mathrm{pH}$, temperature, dissolved oxygen, Biological oxygen demand, turbidity, electrical conductivity, chlorine content, metals present etc. We have studied for a period of 12 months during 2019. Statistical analysis was carried on the studied parameters using SPSS software.

\section{Abbreviations}

DO: Dissolved oxygen; BOD: Biological Oxygen Demand; L: Litre; mg: milli gram; mg/L: milligram/Litre; mm: milli meter; ppm: parts per million; km: kilo meter; $\mu \mathrm{S}$ : micro Siemens; C: Celcius; ${ }^{\circ}$ : Degree; WHO: World Health Organization; WQI: Water Quality Indian; BSI: Bureau of Indian Standard.

\section{Introduction}

Water is the most important compound in shaping the land and regulating the climate. It is one of the crucial compound that is believed to influence life. The water quality is usually described according to the physical, chemical and biological characteristics. The indiscriminate release of chemical fertilizers, pesticides, industrial effluents are causing heavy and varied pollution in the aquatic environment leading to the deterioration of water quality which in turn depletes the aquatic biota.

The use of the contaminated water by human population results in water borne diseases. Hence it is important to check the water quality at a regularly. The present paper investigates some important physicochemical parameters of water samples collected and do a statistical inference on the same. Three lakes in Bengaluru city like Hebbal lake in Northern Bengaluru, Shivpura lake and Elemallappa Shetty Lake in Southern Bengaluru were selected to study the physicochemical parameters, as these lake waters were polluted by industrial effluents, agricultural run off, domestic discharges etc. physicochemical parameters like color, odour, $\mathrm{pH}$, temperature, dissolved oxygen, biological oxygen demand, turbidity, electrical conductivity, chlorine content, metals content like Magnesium, Chromium, Iron, Tin, Mercury, Calcium were studied and statistically analyzed for a period of 12 months from January, 2019 to December, 2019. A general applied mathematics study and analysis on the biophysical and chemical parameters of the lake's surface water quality are applied to seek out the interrelatedness among them and conjointly to understand the water quality trends within the lake. The equation has been derived for the surface water quality parameters similar to the correlation coefficients whose value is over 0.8 . These equations will be used for the fast observation of the surface water quality of the lake. Similarly, a scientific correlation and regression study on the surface water qualities within the study space showed linear relationship among the chosen parameters. This provides an apparent and fast methodology of observation in qualities of the lakes studied. Water quality of the lakes has been determined. Water quality of the lakes is studied to summarize the collected information into easy terms (e.g., 'Good' or 'Bad', 'Clean' or 'Contaminated') for news to authorities, management and 
therefore the public in an exceedingly consistent manner. It is important to note that no work has been reported on Hebbal, Shivpura and Elemallappa Shetty Lakes earlier.

\section{Materials and methods}

\section{Study area}

Hebbal Lake is found within the north of Bangalore at the mouth of National main road seven, on the junction of Bellary Road and also the Outer route (ORR). it absolutely was one in all the 3 lakes created in 1537 by Kempe Gowda. The unfold of the lake in a very study in year 2000 was found to be seventyfive angular distance with plans for extending it to create up 143 angular distance. Shivapura is found 5 kilometers north of Maddur city on the bank of Shimsha watercourse. Shivapura is an element of Mandya taluk in Mandya district, Karnataka. the situation coordinates square measure $13^{\circ} 1^{\prime} 24^{\prime \prime} \mathrm{N} 77^{\circ} 30^{\prime} 23^{\prime \prime} \mathrm{E}$. settled nearer to 1 of Asia's largest industrial parks - the Peenya Industrial Estate- the Shivapura-Nelagadarenahalli lake goes the Bellandur method. Elemallappa Shetty Lake is within the North-Eastern a part of Bengaluru town close to Whitefield. This lake is about 260 acres. This is one in all the biggest lakes in Bengaluru town. This lake has the recent Madras Road passing through it - a road that has very important property from the central Bengaluru through Indiranagar, KR Puram, Hoskote, Chennai.

\section{$\mathrm{pH}$}

$\mathrm{pH}$ is that the measure of acidity of any water solution [13]. The $\mathrm{pH}$ unremarkably ranges from 0 to 14 [1-4]. the size isn't linear rather it's logarithmic. as an example , a solution with a pH of 6 is 10 times additional acidic than a solution with a $\mathrm{pH}$ of seven $[1,3,4,5]$. Pure water is claimed to be neutral, with a $\mathrm{pH}$ of 7 . Water with a $\mathrm{pH}$ below 7.0 is taken under consideration acidic whereas water with $\mathrm{pH}$ bigger than 7.0 is taken under consideration basic or alkalic [6]. The measure of $\mathrm{Ph}$ was done on the location of water collection. $\mathrm{Ph}$ meter was used for detection of $\mathrm{Ph}$ of the collected water samples [7-18].

\section{Temperature}

The temperature of all collected water samples from 3 locations were at intervals of $23^{\circ} \mathrm{C}$ to $31^{\circ} \mathrm{C}$. The minimum temperature was found to be $23.2^{\circ} \mathrm{C}$ in Shivpura Lake within the month of January. Temperature range is found to be low during the post monsoon periods of July and August [19-21]. Pre monsoon months and summer months have an increase in temperature to $30.7^{\circ} \mathrm{C}$. the general seasonal variation in temperature is being observed all-round the year $[21,22]$. The temperature fluctuations don't provide a drastic shock to the sustaining aquatic life [23]. Surface water temperature could also be influenced by factors like geographical position, seasonality, diurnal amount, circulation of air, amount of inclemency, depth of water and its rate [11-16].

\section{Electrical conductivity}

Conductivity is the measure of amount of electric charge which can pass through the water samples [18]. This ability depends on the presence of ions, their total concentration, mobility, valence and relative concentrations, and on the temperature of the liquid [23]. Solutions of most inorganic acids, bases, and salts square measure comparatively smart conductors. The EC of all collected water samples from 3 locations were at intervals of 0.6 to $2.3 \mu \mathrm{S} / \mathrm{cm}$ with a mean of $1.43(\mathrm{SD} \pm 0.85)$. The maximum and minimum of $\mathrm{EC}$ was found to be $0.61 \mu \mathrm{S} / \mathrm{cm}$ and $2.7 \mu \mathrm{S} / \mathrm{cm}$ respectively during the monsoon months. From the study, the measured EC of all water samples collected from Hebbal, Shivpura and Elemallappa Shetty Lake was lower than acceptable range. Within the monsoon season, the flow of the watercourse will increase which can cause the dilution of the salinity of the water, whereas in season, the flow of the watercourse decreases which ends up in increase of EC [21].

\section{Dissolved oxygen (DO)}

DO is defined as the amount of oxygen dissolved in the water samples. It's essential for respiration of fish and other aquatic organisms [3]. DO enters water by diffusion from the atmosphere, as a by product of chemical process by protists or through photosynthesis performed by plants [24-30]. The concentration of DO in waters depends on the organisms surviving in it, because all metabolic processes taking place utilizes the dissolved oxygen available [9]. Excessive protist or other microorganism in the aquatic environment depletes the amount of dissolved oxygen and it affects the metabolic processes performed by other macro organisms [10-16]. Other processes like decomposition of dead performed by different scavengers in the aquatic environment utilizes the dissolved oxygen $[11,12]$. Fish want a minimum of $3-5 \mathrm{mg} / \mathrm{L}$ of DO to survive $[21,23,30-34]$. DO is observed to vary within the range of $13.13 \mathrm{mg} / \mathrm{L}$ to $28.28 \mathrm{mg} / \mathrm{L}$ with the mean of 19.98 $\mathrm{mg} / \mathrm{L}$. Winkler's method was carried out on the site of sample collection to measure the DO [25]. About $1 \mathrm{ml}$ of manganous sulphate, $1 \mathrm{ml}$ of potassium/sodium azide are added to 120 $\mathrm{ml}$ of sample water samples from the three distinct sites [25]. Brown precipitation was observed which indicated the presence of dissolved oxygen in the collected water samples $[9,25,29,35]$. About $1 \mathrm{ml}$ of concentrated $\mathrm{H}_{2} \mathrm{SO}_{4}$ was added and titrated against sodium thiosulphate and starch solution was used as an indicator $[25,29]$. The colour change from blue to pale yellow marked the level of DO content [25,11].

\section{Turbidity}

Turbidity is defined as the cloudiness or haziness of a fluid. It can be caused by large numbers of individual particles that are generally invisible to the naked eye [36-38]. Water samples were collected from three distinct lakes and a nephelometer or turbidimeter was used to measure turbidity of each water sample[39]. Nephelometer or turbidimeter is an instrument which measures the intensity of light scattered at 90 degrees as a beam of light passes through a water sample [40]. It is observed that turbidity varied within the range of 0.35 NTU to 10.9 NTU. The mean is found to be $4.822 \mathrm{NTU}(\mathrm{SD} \pm 4.522)$.

\section{Biological oxygen demand (BOD)}

Biological oxygen demand (BOD) is that the quantity of dissolved oxygen element required (i.e. demanded) by aerobic 
biological organisms to break down the organic materials at a certain temperature over a specified time interval [41-43]. The water samples were collected from each study site in $120 \mathrm{ml}$ BOD bottles and kept in kept in incubation for 5 days $[40,44]$. After 5 days the DO was measured using Winkler's method. The difference between the readings of DO (Day 1) and DO (Day 5) gives the BOD reading $[40,45-47]$. The difference between the two DO levels represents the amount of oxygen required for the decomposition of any organic material in the samples [48-50]. The mean of BOD was observed to be 8.08 ( $S D \pm 10.456$ ). The decrease in DO level in the water sample of Elemallappa Shetty Lake was more compared to other water samples. This may be because the organic material content in the water sample collected from Elemallappa Shetty Lake is more comparatively.

\section{Platinum cobalt unit test}

Water samples from three distinct sites were collected and kept at room temperature [8]. The collected water samples were analyzed within 7 days of collection. Samples were filtered using filters of defined pore size. The $0.45 \sim \mathrm{m}$ filters were used for routine filtration. Standard color solutions were prepared by dilution of standard platinum chloride ( $\mathrm{I} \mathrm{ms} / \mathrm{ml}$,) and cobalt chloride $\left(\mathrm{CoCl} .6 \mathrm{H}_{2} \mathrm{O}\right)$ solution. The molar ratio of Pt :Co its the standard color solution is 2:1 the concentration of Pt in $\mathrm{mg} / \mathrm{i}$ is equal to the "color" in PTU [8]. Color was determined using turbidimeter. The detection of water color specify the extent to which collected water samples are polluted [8]. Shivpura lake water samples had the highest NTU compared to other water samples.

\section{Metal analysis}

The acid-available fraction of metals $(\mathrm{Sn}, \mathrm{Mg}, \mathrm{Hg}, \mathrm{Fe}$, $\mathrm{Ca}, \mathrm{Cr}, \mathrm{Pb})$ was determined [6,24,51-53]. The data quality was checked by careful standardization, procedural blank measurements, spiked and duplicate samples [54,55]. Atomic Absorption Spectroscopy was used for detection and analysis of metal traces present in the water samples collected [24, $29,56,57]$

\section{Statistical analysis}

The correlation analysis on surface water quality parameters reveals that all parameters are more or less correlated with each other. The correlation coefficient $(r)$ of $>0.8$ was taken Windows Excel were used as the statistical analysis tool. The term correlation (or co-variation) indicates the relationship between two variables such that the changes in the values of one variable cause the value of the other variable to change. We can establish inter-relationship between variables by statistical methods with a few sets of observations. It gives a rough but fairly useful indication of the water quality and also facilitates a rapid monitoring of the status of water pollution. Statistical investigation offers more attractive options in environmental science, though the results may deviate more from real situations. The correlation provides an excellent tool for the prediction of parametric values within a reasonable degree of accuracy [58]. The quality of water is described by in to account to find the regression equations. The SPSS and

its physical, chemical and microbial characteristics. But, if some correlations are possible among these parameters, then the more significant ones would be useful to indicate fairly the quality of water $[10,59,60]$.

\section{Discussion}

One of the troublesome task faced by the scientists is to transfer their interpretation of complicated environmental knowledge into information that is graspable and helpful to technical, policy makers and the general public. This can be significantly necessary in examination of the condition of the surroundings. Internationally, there are variety of pacts to provide a way that means absolutely integrates data and converts them into information. This study is administered to gauge the connection between different physicochemical parameters, metal content and assess the water quality of Hebbal, Shivpura and Elemallappa Shetty Lakes. The standard of water is that the resultant of all the processes and reactions that act on the water from the instant it condensed within the atmosphere to the time it gets discharged by a well or spring and varies from place to place and with the depth of the water table. The correlation coefficients of studied parameters are tabulated in Tables 1.0 to 2.1. The study reveals the following relationships. $\mathrm{pH}$ has significant relationship between dissolved oxygen (DO), biological oxygen demand (BOD). There is no significant relationship between $\mathrm{pH}$ and Temperature, Turbidity, Chlorine content, platinum cobalt unit (PCU). There is significant relationship between dissolved oxygen (DO) with temperature, Electrical conductivity. There is significant relationship between Electrical conductivity and chlorine content. There is significant relationship between platinum cobalt unit (PCU) and biological oxygen demand (BOD), chlorine content and Electrical conductivity. Significant relationship is observed between metals like $\mathrm{Sn}, \mathrm{Mg}$, Fe, $\mathrm{Hg}$, Ca and $\mathrm{Cr}$ with parameters such as Electrical conductivity, Turbidity, platinum cobalt unit (PCU). According to Indian Standard drinking water specifications (2012), $\mathrm{pH}$ of water from all the lakes are within permissible range 6.5-8.5, Chlorine content in water should be or less than $4 \mathrm{mg} / \mathrm{l}$ or $4 \mathrm{ppm}$ for considering it safe

Table 1.0: Physico-chemical parameters observed in Hebbal Lake water.

\begin{tabular}{|c|c|c|c|c|c|c|c|c|}
\hline Months & pH & DO & Tempe--rature & Turbi- dity & BOD & $\begin{array}{c}\text { Electrical } \\
\text { Conduct } \\
\text {-ivity }\end{array}$ & $\begin{array}{c}\text { Chlorine } \\
\text { Content }\end{array}$ & PCU \\
\hline January & 7.0 & 21.21 & 24 & 0.34 & 4.04 & 2.3 & 0.03 & 77 \\
\hline February & 6.8 & 18.18 & 26.5 & 0.38 & 2.02 & 2.0 & 0.02 & 73 \\
\hline March & 7.6 & 17.17 & 26 & 0.38 & 11.11 & 2.61 & 0.01 & 68 \\
\hline April & 7.2 & 15.15 & 31 & 0.37 & 8.08 & 1.08 & 0.02 & 69 \\
\hline May & 7.6 & 16.16 & 27.5 & 0.35 & 9.09 & 2.82 & 0.01 & 71 \\
\hline June & 7.4 & 18.18 & 29 & 0.36 & 12.12 & 2.5 & 0.03 & 73 \\
\hline July & 6.9 & 19.19 & 30.7 & 0.35 & 7.07 & 2.6 & 0.01 & 76 \\
\hline August & 7.2 & 22.22 & 29 & 0.37 & 4.04 & 2.41 & 0.02 & 67 \\
\hline September & 7.2 & 36.36 & 27 & 0.36 & 20.2 & 2.5 & 0.03 & 77 \\
\hline October & 7.5 & 26.26 & 25 & 0.39 & 8.08 & 2.7 & 0.01 & 80 \\
\hline November & 6.9 & 16.16 & 26 & 0.36 & 9.09 & 2.62 & 0.02 & 75 \\
\hline December & 7.1 & 23.23 & 25 & 0.37 & 4.04 & 2.5 & 0.02 & 76 \\
\hline
\end{tabular}

Citation: Chatterjee A, Ganesh S (2020) Analysis of physicochemical parameters of the Hebbal, Shivpura, Elemallappa Shetty Lakes in Bengaluru City, India. Ann Limnol Oceanogr 5(1): 001-007. DOI: https://dx.doi.org/10.17352/alo.000009 
for consumption, agriculture and fisheries. The average of chlorine content in water samples was $0.03 \mathrm{mg} / \mathrm{l}$ thus, safe for use. Iron content in water should be within $0.3 \mathrm{mg} / \mathrm{l}$ but in water samples collected from Elemallappa Shetty Lake is 1.4

Table 1.1: Metals (ppm) observed in Hebbal Lake

\begin{tabular}{|c|c|c|c|c|c|c|}
\hline Months Sn & $\mathbf{M g}$ & $\mathbf{H g}$ & $\mathbf{F e}$ & $\mathbf{C a}$ & $\mathbf{C r}$ & \\
\hline January 3.57 & 1.52 & 0.92 & 0 & 0.62 & 0.12 & \\
\hline February & 4.23 & 1.71 & 0.98 & 0.3 & 0.31 & 0 \\
\hline March 25 & 1.62 & 2.1 & 0.1 & 0.12 & 0.02 & \\
\hline April 24.09 & 0.12 & 2.63 & 0.02 & 0.32 & 0 & \\
\hline May 24.6 & 0.76 & 2.31 & 0.09 & 0.34 & 0 & \\
\hline June 23.4 & 0.54 & 2.72 & 0.07 & 0.19 & 0 & \\
\hline July 22.93 & 0.21 & 2.42 & 0.06 & 0.21 & 0 & \\
\hline August 24.32 & 1.44 & 0.98 & 1.24 & 0 & 0 & \\
\hline September & 29.5 & 1 & 0 & 0.23 & 0.88 & 0 \\
\hline October 25.93 & 1.678 & 2.24 & 0.1 & 1.72 & 0.12 & \\
\hline November 22.54 & 1.76 & 0.84 & 0 & 12.73 & 0.125 & \\
\hline December & 3.33 & 1.65 & 0.62 & 0 & 15.34 & 0.42 \\
\hline
\end{tabular}

Table 1.2: Physico-chemical parameters observed in Shivpura Lake.

\begin{tabular}{|c|c|c|c|c|c|c|c|c|}
\hline Months & pH & Do & $\begin{array}{c}\text { Tempe- } \\
\text {-rature }\end{array}$ & $\begin{array}{c}\text { Turbi- } \\
\text { dity }\end{array}$ & BOD & $\begin{array}{c}\text { Electrical } \\
\text { Conduct } \\
\text {-ivity }\end{array}$ & $\begin{array}{c}\text { Chlorine } \\
\text { Content }\end{array}$ & PCU \\
\hline January & 6.9 & 19.19 & 22.3 & 10.6 & 9.09 & 1.03 & 0.01 & 218 \\
\hline February & 7.4 & 21.21 & 22.6 & 10.9 & 9.09 & 1.02 & 0.01 & 215 \\
\hline March & 6.8 & 20.2 & 32.5 & 10.6 & 3.03 & 1.05 & 0.02 & 219 \\
\hline April & 7.1 & 18.18 & 33.5 & 10.9 & 5.05 & 2.7 & 0.03 & 216 \\
\hline May & 7.8 & 17.17 & 25 & 11 & 9.09 & 1.08 & 0.02 & 216 \\
\hline June & 7.4 & 21.21 & 25.4 & 10.7 & 4.04 & 1.07 & 0.02 & 217 \\
\hline July & 7.2 & 20.2 & 27 & 11 & 4.04 & 1.03 & 0.02 & 218 \\
\hline August & 7.5 & 16.16 & 26.7 & 10.5 & 4.04 & 1.06 & 0.02 & 213 \\
\hline September & 7.2 & 15.15 & 29 & 10.6 & 6.06 & 1.09 & 0.01 & 215 \\
\hline October & 7.1 & 16.16 & 29 & 10.8 & 4.04 & 1.06 & 0.02 & 217 \\
\hline November & 6.8 & 13.13 & 24 & 12 & 5.05 & 1.07 & 0.03 & 217 \\
\hline December & 7.4 & 17.17 & 24.8 & 10.7 & 8.08 & 1.05 & 0.02 & 220 \\
\hline
\end{tabular}

Table 1.3: Metals (ppm) observed in Shivpura Lake.

\begin{tabular}{|c|c|c|c|c|c|c|}
\hline Months $\mathbf{S n}$ & $\mathbf{M g}$ & $\mathbf{H g}$ & $\mathbf{F e}$ & $\mathbf{C a}$ & $\mathbf{C r}$ & \\
\hline January 22.67 & 1.54 & 1.82 & 0.1 & 0.5 & 0 & \\
\hline February & 23.17 & 1.51 & 2.13 & 0.13 & 0.13 & 0 \\
\hline March 24.32 & 1.64 & 2.4 & 0.02 & 0.04 & 0.3 & \\
\hline April 24.13 & 1.54 & 2.1 & 0.01 & 0.21 & 0 & \\
\hline May 23.9 & 1.9 & 2.92 & 0.12 & 0.12 & 0 & \\
\hline June 23.7 & 2.7 & 2.52 & 0.11 & 0.21 & 0 & \\
\hline July 23.1 & 2.34 & 2.71 & 0.17 & 0.3 & 0 & \\
\hline August 29.62 & 1.89 & 0.44 & 0.54 & 0 & 0 & \\
\hline September & 20.23 & 0.6 & 0.98 & 0.02 & 1.54 & 0 \\
\hline October 24.98 & 1.67 & 2.61 & 0.02 & 1.49 & 0.06 & \\
\hline November & 23.18 & 1.83 & 1.08 & 0 & 6.72 & 1.225 \\
\hline December & 22.92 & 1.39 & 1.05 & 0 & 7.39 & 1.31 \\
\hline
\end{tabular}

Table 1.4: Physico-chemical parameters observed in Elemallappa Shetty Lake.

\begin{tabular}{|c|c|c|c|c|c|c|c|c|}
\hline Months & pH & DO & $\begin{array}{c}\text { Tempe- } \\
\text {-rature }\end{array}$ & $\begin{array}{c}\text { Turbi- } \\
\text { dity }\end{array}$ & BOD & $\begin{array}{c}\text { Electrical } \\
\text { Conduct } \\
\text {-ivity }\end{array}$ & $\begin{array}{c}\text { Chlorine } \\
\text { content }\end{array}$ & PCU \\
\hline January & 6.2 & 17.17 & 24.3 & 3.2 & 1.01 & 0.63 & 0.02 & 5 \\
\hline February & 7.4 & 9.9 & 23.7 & 3.3 & 3.8 & 0.68 & 0.02 & 7 \\
\hline March & 7.1 & 21.21 & 27 & 3.5 & 2.02 & 0.64 & 0.03 & 6 \\
\hline April & 6.9 & 20.2 & 34 & 3.2 & 12.12 & 0.6 & 0.01 & 8 \\
\hline May & 7.3 & 23.23 & 31.5 & 3.4 & 3.18 & 0.68 & 0.03 & 7 \\
\hline June & 7.1 & 19.19 & 27 & 3 & 7.07 & 0.69 & 0.03 & 8 \\
\hline July & 6.8 & 24.24 & 27.9 & 3.3 & 3.03 & 0.73 & 0.03 & 9 \\
\hline August & 7 & 34.34 & 31.3 & 3.4 & 4.31 & 0.63 & 0.01 & 7 \\
\hline September & 7 & 7.07 & 28 & 3 & 18.18 & 0.61 & 0.02 & 6 \\
\hline October & 7.3 & 19.19 & 27.5 & 3.1 & 1.01 & 0.71 & 0.03 & 8 \\
\hline November & 7 & 18.18 & 25.5 & 3.3 & 12.12 & 0.66 & 0.03 & 9 \\
\hline December & 7.3 & 28.28 & 25 & 3 & 11.11 & 0.62 & 0.03 & 7 \\
\hline
\end{tabular}

Table 1.5: Metals (ppm) observed in Elemallappa Shetty Lake.

\begin{tabular}{|l|l|l|l|l|l|l|}
\hline Months & Sn & Mg & Hg & Fe & Ca & Cr \\
\hline January & 23.72 & 1.52 & 0.98 & 1.13 & 0.13 & 1.20 \\
\hline February & 24.34 & 1.49 & 1.32 & 2.12 & 0.10 & 1.1 \\
\hline March & 24.21 & 1.31 & 1.9 & 3 & 0.02 & 0.04 \\
\hline April & 24.19 & 0.3 & 2.72 & 2.3 & 0.16 & 0 \\
\hline May & 24.2 & 0.64 & 2.66 & 3.2 & 0.52 & 0 \\
\hline June & 23.89 & 0.7 & 2.53 & 1.83 & 0.41 & 0 \\
\hline July & 22.84 & 0.16 & 2.37 & 1.37 & 0.32 & 0 \\
\hline August & 28.21 & 1.67 & 0.23 & 2.21 & 0 & 0 \\
\hline September & 25.2 & 0.8 & 0.71 & 0.06 & 0.54 & 0 \\
\hline October & 24.38 & 1.29 & 2.61 & 3.52 & 1.45 & 0.22 \\
\hline November & 23.53 & 1.81 & 0.81 & 0 & 25.31 & 2.35 \\
\hline December & 22.12 & 1.73 & 0.51 & 0 & 31.26 & 2.51 \\
\hline
\end{tabular}

Table 1.6: Correlation matrix of Hebbal Lake physico chemical parameters.

\begin{tabular}{|c|c|c|c|c|c|c|c|c|}
\hline & pH & Do & $\begin{array}{c}\text { Tem-per } \\
\text { ature }\end{array}$ & $\begin{array}{c}\text { Turb- } \\
\text { idity }\end{array}$ & BOD & $\begin{array}{c}\text { Electrical } \\
\text { Conduct } \\
\text {-ivity }\end{array}$ & $\begin{array}{c}\text { Chlorine } \\
\text { Content }\end{array}$ & PCU \\
\hline Ph & 1.00 & & & & & & \\
\hline DO & 0.022 & 1.00 & & & & & \\
\hline $\begin{array}{c}\text { Tem- per } \\
\text { ature }\end{array}$ & -0.030 & -0.275 & 1.00 & & & & & \\
\hline $\begin{array}{c}\text { Turb- idity } \\
\text { BOD }\end{array}$ & 0.250 & 0.08 & -0.126 & 1.00 & & & & \\
\hline $\begin{array}{c}\text { Electrical } \\
\text { Conduc } \\
\text {-tivity }\end{array}$ & 0.289 & 0.498 & 0.127 & -0.09 & 1.00 & & & \\
\hline $\begin{array}{c}\text { Chlorine } \\
\text { Content }\end{array}$ & -0.331 & 0.344 & -0.417 & -0.14 & 0.206 & 1.00 & & \\
\hline PCU & -0.267 & 0.518 & -0.476 & -0.12 & 0.116 & 0.332 & 0.155 & 1.00 \\
\hline
\end{tabular}

$\mathrm{mg} / \mathrm{l}$ in average thus, should not be considered for direct use in homes, fields and fishery sectors without prior treatment. Magnesium $\left(\mathrm{Mg}^{2+}\right)$ content should be within $30 \mathrm{mg} / \mathrm{l}$ and all the collected samples had $2.32 \mathrm{mg} / \mathrm{l} \mathrm{of} \mathrm{Mg}^{2+}$ in average, thus safe for other uses. Chromium content should be $0.1 \mathrm{mg} / \mathrm{l}$ or 
less, Hebbal Lake water samples are safe for use since the Chromium content was less, but for Shivpura and Elemallappa Shetty Lake water, pre use treatment is required before use.

Table 1.7: Correlation matrix of Hebbal Lake metals observed

\begin{tabular}{|c|c|c|c|c|c|c|}
\hline & Sn & Mg & Hg & Fe & Ca & Cr \\
\hline $\mathrm{Sn}$ & 1.00 & & & & & \\
\hline $\mathrm{Mg}$ & -0.415 & 1.00 & & & & \\
\hline $\mathrm{Hg}$ & 0.377 & -0.591 & 1.00 & & & \\
\hline $\mathrm{Fe}$ & 0.164 & 0.171 & -0.26 & 1.00 & & \\
\hline $\mathrm{Ca}$ & -0.348 & 0.426 & -0.43 & -0.271 & 1.00 & \\
\hline $\mathrm{Cr}$ & -0.565 & 0.467 & -0.375 & -0.286 & 0.846 & 1.00 \\
\hline
\end{tabular}

Table 1.8: Correlation matrix of Shivpura Lake physico chemical parameters.

\begin{tabular}{|c|c|c|c|c|c|c|c|c|}
\hline & pH & DO & $\begin{array}{l}\text { Tem- } \\
\text { per } \\
\text { ature }\end{array}$ & $\begin{array}{l}\text { Turb- } \\
\text { idity }\end{array}$ & BOD & $\begin{array}{c}\text { Electrical } \\
\text { Conduct } \\
\text {-ivity }\end{array}$ & $\begin{array}{l}\text { Chlorine } \\
\text { Content }\end{array}$ & PCU \\
\hline $\mathrm{pH}$ & 1.00 & & & & & & & \\
\hline DO & 0.113 & 1.00 & & & & & & \\
\hline $\begin{array}{c}\text { Tem- } \\
\text { perature }\end{array}$ & -0.280 & -0.024 & 1.00 & & & & & \\
\hline Turb- Idity & -0.267 & -0.446 & -0.239 & 1.00 & & & & \\
\hline BOD & 0.373 & 0.055 & -0.643 & $\begin{array}{c}- \\
0.008\end{array}$ & 1.00 & & & \\
\hline $\begin{array}{c}\text { Electrical } \\
\text { Condu- } \\
\text { ctivity }\end{array}$ & -0.112 & 0.003 & 0.596 & 0.038 & $\begin{array}{c}- \\
0.124\end{array}$ & 1.00 & & \\
\hline $\begin{array}{l}\text { Chlorine } \\
\text { Content }\end{array}$ & -0.173 & -0.336 & 0.394 & 0.568 & $\begin{array}{c}- \\
0.485\end{array}$ & 0.521 & 1.00 & \\
\hline PCU & -0.4026 & 0.230 & 0.008 & 0.068 & 0.010 & -0.135 & 0.124 & 1.00 \\
\hline
\end{tabular}

Table 1.9: Correlation matrix of Shivpura Lake metals observed.

\begin{tabular}{|c|c|c|c|c|c|c|}
\hline & Sn & Mg & Hg & Fe & Ca & Cr \\
\hline $\mathrm{Sn}$ & 1.00 & & & & & \\
\hline $\mathrm{Mg}$ & 0.398 & 1.00 & & & & \\
\hline $\mathrm{Hg}$ & -0.173 & 0.460 & 1.00 & & & \\
\hline $\mathrm{Fe}$ & 0.772 & 0.311 & -0.317 & 1.00 & & \\
\hline $\mathrm{Ca}$ & -0.250 & -0.209 & -0.490 & -0.394 & 1.00 & \\
\hline $\mathrm{Cr}$ & -0.151 & -0.110 & 0.438 & -0.363 & 0.960 & 1.00 \\
\hline
\end{tabular}

Table 2.0: Correlation matrix of Elemallappa Shetty Lake physico chemical parameters.

\begin{tabular}{|c|c|c|c|c|c|c|c|c|}
\hline & pH & DO & $\begin{array}{c}\text { Temp- } \\
\text { rature }\end{array}$ & $\begin{array}{c}\text { Turb- } \\
\text { idity }\end{array}$ & BOD & $\begin{array}{c}\text { Electrical } \\
\text { Conducti } \\
\text {-ivity }\end{array}$ & $\begin{array}{c}\text { Chlorine } \\
\text { Content }\end{array}$ & PCU \\
\hline Ph & 1.00 & & & & & & \\
\hline DO & 0.020 & 1.00 & & & & & \\
\hline Temp- Rature & 0.051 & 0.372 & 1.00 & & & & \\
\hline $\begin{array}{c}\text { Turb- Idity } \\
\text { BOD }\end{array}$ & -0.016 & 0.307 & 0.220 & 1.00 & & & \\
\hline $\begin{array}{c}\text { Electrical } \\
\text { Conduc- }\end{array}$ & 0.090 & 0.31 & 0.137 & -0.513 & 1.00 & & \\
tivity & 0.242 & 0.010 & -0.20 & 0.115 & -0.55 & 1.00 & \\
\hline $\begin{array}{c}\text { Chlorine } \\
\text { Content }\end{array}$ & 0.298 & -0.03 & -0.458 & -0.08 & -0.20 & 0.599 & 1.00 & \\
\hline PCU & 0.303 & 0.207 & 0.203 & -0.03 & 0.115 & 0.541 & 0.259 & 1.00 \\
\hline
\end{tabular}

Table 2.1: Correlation matrix of Elemallappa Shetty Lake metals observed.

\begin{tabular}{|c|c|c|c|c|c|c|}
\hline & Sn & Mg & Hg & Fe & Ca & Cr \\
\hline $\mathrm{Sn}$ & 1.00 & & & & & \\
\hline $\mathrm{Mg}$ & 0.159 & 1.00 & & & & \\
\hline $\mathrm{Hg}$ & -0.291 & -0.728 & 1.00 & & & \\
\hline $\mathrm{Fe}$ & 0.304 & -0.238 & 0.659 & 1.00 & & \\
\hline $\mathrm{Ca}$ & -0.471 & 0.520 & -0.460 & -0.637 & 1.00 & \\
\hline $\mathrm{Cr}$ & -0.481 & 0.683 & -0.555 & -0.635 & 0.885 & 1.00 \\
\hline
\end{tabular}

All the water samples contain Calcium within permissible limit that is $75 \mathrm{mg} / \mathrm{l}$, thus safe for use. Overall, Hebbal and Shivpura Lake water samples are of good quality but Elemallappa Shetty Lake is of poor quality. Elemallappa Shetty Lake water contains most amount of pollutants and need pre use water treatment. Based on this study it is been found that water resources potential analysis in terms of quantification of surface water is important to evolve water resources development plans for the lakes in metropolitan cities like Bengaluru. Initiatives are taken to popularize the programs among the general public, particularly farmers at numerous levels, that ought to be created effective thus on attain self-sufficiency within the property water resources development. Prioritization ought to run within the over-extracted areas in the city thus on conservation of the water and for designing acceptable structures to be placed into action.

\section{Conclusion}

The results of seasonal variation and physico-chemical study of the lake water samples, helps us to conclude regarding the quality of the water samples studied. The $\mathrm{pH}$ of the water has an effect on the life forms. The samples have carbonate $\left(\mathrm{CO}_{3}{ }^{2-}\right)$, traditional salt $\left(\mathrm{SO}_{4}{ }^{2-}\right)$ and are moderately alkaline in nature. The comparison of analyzed information with UN agency, ISI and BIS fascinating limit indicates that the water samples are moderately appropriate for drinking. In different sectors like industries, fisheries, micro-irrigation like drip- and sprinklerirrigation can be done using the water of Hebbal and Shivpura Lakes. Water of Elemallappa Shetty Lake is comparatively polluted due to dumping of industrial wastes. Pre use water treatment is necessary for the water of Elemallappa Shetty Lake. The quality of surface water depends on the different types of rocks present in the area. Major portion of the Shivpura and Elemallappa Shetty Lake is covered with hard and sedimentary rocks. Hardness is due to presence of Calcium, Magnesium, Bicarbonate and Chloride ions from the presence of rocks. The presence of major cations like Calcium, Magnesium, Iron was found to be within the permissible range thus, the water from all the three sites were suitable for using domestically and for agricultural purposes. We should protect the lakes in the city rather than dumping the industrial effluents and domestic wastes in the water bodies carelessly.

\section{Acknowledgement}

I cannot express enough thanks to God, my supervisor and Associate professor, Ganesh S, and Head of the Department, Fr. Jobi Xavier, for their continued support and encouragement. 
I offer my sincere appreciation for the learning opportunities provided by Head of the Institute, CHRIST (Deemed to be University), Bangalore. My completion of this project could not have been accomplished without the support of my professors, Lab assistant, classmates. Thanks to my parents Mr. Jaydip Chatterjee and Mrs. Sonali Chatterjee for their lovely support throughout the project work.

\section{References}

1. Bateman A (1960) 'Economic Mineral Deposits. Asia Publishing, New York 788.

2. Boritz JF, Kennedy DB (1995) Effectiveness of neural network types for prediction of business failure. Expert Systems with Applications 9: 503-512 Link: https://bit.ly/3eL2Sf1

3. Cerling TE, Pederson BL, von Damm KL (1989) Sodium-calcium ion exchange in the weathering of shales: Implications for global weathering budgets. Geology 17: 552-554. Link: https://bit.ly/30iNtPd

4. Basnyat $P$, Teeter LD, Lockaby BG, Flynn KM (2000) The use of remote sensing and GIS in watershed level analyses of non-point source pollution problems. Forest Ecology and Management 128: 65-73. Link: https://bit.ly/3cyBfEg

5. Buntine WL, Weigend AS (1991) Bayesian Back-propagation. Complex Systems 5: 603-643. Link: https://bit.ly/2Mqgvnx

6. Chakraborty K, Mehrotra K, Mohan CK, Ranka S (1992) Forecasting the behavior of multivariate time series using neural network. Neural networks 5 : 961-970. Link: https://bit.ly/2BqFmW8

7. Cude C Oregon Department of Environmental Quality", Laboratory Division Oregon EA (Online). Link: https://bit.ly/3cwoGth

8. Das J, Acharya BC (2003) Hydrology and assessment of lotic wate quality in Cuttack City, India. Water Air Soil Pollut 150: 163-175. Link: https://bit.ly/2XXnN7H

9. Dash JR, Dash PC, Patra HK (2006) A Correlation and regression Study on the ground water quality in rural areas around Angul-Talcher Industrial zone. Indian Journal of Environmental Protection 26: 550-558. Link: https://bit.ly/3gPbP8N

10. Davis and Dewiest “Hydrology”, John Wiley, New York, pp.463, 1966.

11. Dethier DP (1988) A hydrogeochemical model for stream chemistry, Cascade Range, Washington, U.S.A. Earth Surface Recesses and Landforms 13: 321 333. Link: https://bit.ly/2U5Kkhp

12. Dhembare A, Pondhe GM (1997) Correlation of ground waste quality parameters of Sonai area (Maharashtra). Pollution Research 16: 189-199.

13. Diamantopoulou Maria J, Antonopoulos Vassilis Z, Papamichail DM (2007) Cascade correlation arti¿cial neural networks for estimating missing monthly values of water quality parameters in rivers. Water Resour Manage 21: 649662. Link: https://bit.ly/3cvy6W2

14. El Tabach E, Lancelot L, Shahrour I, Najjar Y (2007) Use of articcial neural network simulation metamodelling to assess groundwater contamination in a road project. Mathematical and Computer Modelling 45: 766-776. Link: https://bit.ly/2AEJAsM

15. Edmunds WM, Walton NRG (1983) The Lioncolnshire limestoneHydrogeochemical evolution over a ten year period. Journal of Hydrogeology 61: 201-122. Link: https://bit.ly/2U8pKgJ

16. Elango L (1992) Hydrogeochemistry and modelling of multilayer aquifers. Ph.D. Thesis, Anna University, Chennai, India.

17. Elango L, Kannan R, Senthil Kumar M (2003) Major ion chemistry and identification of hydrogeochemical processes of groundwater in a part of Kancheepuram District, Tamil Nadu, India. Environmental Geosciences 10 157-166. Link: https://bit.ly/2XXw0c9

18. Elango L, Rajmohan N, Gnanasundar D (1999) Groundwater quality monitoring in intensively cultivated regions of Tamil Nadu, India", Weaver T.R. and Lawrence C.R. (Eds.), Proceedings on Groundwater Sustainable Solution, University of Melborne, Australia, 637- 643.

19. Bandyopadhyay G, Chattopadhyay S (2007) Single hidden layer artificial neural network models versus multiple linear regression model in forecasting the time series of total ozone. Int J Environ Sci Tech 4: 141-149. Link: https://bit.ly/3dz7DYN

20. Biswal SK, Maythi B, Behera JP (2001) Ground water quality near ash pond of thermal power plant. Pollution Research 20: 487-490.

21. Ferguson RI, Trudgill ST, Ball J (1994) Mixing and uptake of solutes in catchments: model development. Journal of Hydrology 159: 223-233. Link: https://bit.ly/2MrgCPT

22. El-shafie AE, Noureldin AE, Taha MR, Basri H (2008) Neural network mode for Nile River inflow forecasting analysis of historical inflow data. Journal of Applied Sciences 8: 4487-4499. Link: https://bit.ly/2AFH6dD

23. Freeze RA, Cherry JA (1979) Ground Water Floe, New Jersey, Prentice- Hall Inc, 15-77.

24. Chen Q, Mynett AE (2003) Integration of data mining techniques and heuristic knowledge in fuzzy logic modelling of eutrophication in Taihu Lake. Ecological Modelling 162: 55-67. Link: https://bit.ly/2Bp1Qqu

25. Chenini I, Khemiri S (2009) Evaluation of ground water quality using multiple linear regression and structural equation modeling. Int J Environ Sci Tech 6 509- 519. Link: https://bit.ly/3eOD5Cw

26. Chimwanza B, Mumba PP, Moyo BHZ, Kadewa W (2006) The impact of farming on river banks on water quality of the rivers. Int J Environ Sci Tech 2: 353-358. Link: https://bit.ly/2Mp27vU

27. Chun KC, Chan RW, Williams GP (2001) Water quality issues in the Nakdong River Basin in the Republic of Korea. Journal of Environmental Engineering and Policy 2: 131-143. Link: https://bit.ly/2XXoGgx

28. Collet C, Consuegra D, Joerin F (1996) GIS Needs and GIS Software. Kluwer Academic Publishers 115-142. Link: https://bit.ly/303lhzz

29. Conway (1942) Mean geochemical data in relation to oceanic evolution Geochim Cosmochim Acta 8: 22-48.

30. Couillard D, Lefebvre Y (1985) Analysis of water quality indices. Journal of Environment Management 21: 161-179. Link: https://bit.ly/3eOBLzy

31. Hegde GR, Kale YS (1995) Quality of lentic waters of Dharwad District in North Karnataka. Indian J Environ HIth 37: 52-56. Link: https://bit.ly/3gS8A01

32. Garg DK, Goyal RK, Agarwal VP (1990) Correlation among water quality parameters of groundwater of Roorkee city. Indian Journal of Environmental Protection 10: 355-359.

33. Gibbs RJ (1970) Mechanisms controlling world's water chemistry. Science 170: 1088- 1090. Link: https://bit.ly/2Mtz5LC

34. Gorham E (1961) Factors influencing supply of major ions to inland waters with special reference to the atmosphere. Bull Geol Soc Amer 72: 795-840. Link: https://bit.ly/3eUiNYB

35. Bowers JA, Shedrow CB (2000) Predicting stream water quality using artificial neural networks. U.S. Department of Energy Report WSRCMS-2000-00112 7-14. Link: https://bit.ly/2XteRli

36. Gorr WL, Nagin D, Szcypula J (1994) Comparative study in artificial neura network and stastistical models for predicting student grade point averages. Internation Journal of Forecasting 10: 17-34. Link: https://bit.ly/2U6h36g 
37. Gray AR, MacDonell SG (1997) A comparison of techniques for developing predictive models of software metrics. Information and Software Technology 39: 425-437. Link: https://bit.ly/2XwLt3Z

38. Grubert JP (2003) Acid deposition in the eastern United States and neural network predictions for the future. Journal of Environmental Engineering and Science 2: 99-109. Link: https://bit.ly/2MtcHSB

39. Groves CG (1992) Geochemical and kinetic evolution of a karst flow system, Laurel creek, West Virginia. Groundwater 30: 186-191. Link: https://bit.ly/2XYMbWv

40. Maier HR, Dandy GC (2000) Neural networks for the prediction and forecasting of water sources variables: a review of modelling issues and applications. Environmental Modelling and Software 15: 101-124.

41. Juahir H, Zain S, Toriman MI, Mokhtar M, Man HC (2004) Application of artificial neural network models for predicting water quality index. Jurnal Kejuruteraan Awam 16: 42-55. Link: https://bit.ly/3eP59pA

42. Harilal CC, Hashim A, Arun PR, Baji S (2004) Hydrogeochemistry of two rivers of Kerala with special reference to drinking water quality. J Ecology Env Conservation 10: 187-192. Link: https://bit.ly/3dJoOHr

43. Hem JD (1970) Study and interpretation of the chemical characteristics of natural water. USGS Water Supply Paper 1473: 363

44. Elhatip HM, Aydin Komur M (2008) Evaluation of water quality parameters for the Mamasin dam in Aksaray City in the central Anatolian part of Turkey by means of artificial neural networks. Environ Geol 53: 1157-1164. Link: https://bit.ly/2Mq8Sxp

45. Hendry MJ, Schwartz FW (1990) The chemical evaluation of groundwater in the Milk river aquifer Canada. Groundwater 28: 253-261. Link: https://bit.ly/2U8hFly

46. Maier HR, Dandy GC (2000) Neural networks for the prediction and forecasting of water sources variables: a review of modelling issues and applications. Environmental Modelling and Software 15: 101-124. Link: https://bit.ly/3cyoPfA

47. Hendry MJ, Schwartz FW (1990) "The chemical evaluation of groundwater in the Milk river aquifer, Canada", Groundwater 23: 4-9.

48. Harrison R, Swift RS, Campbell AS, Tonkin PJ (1990) A study of two soil development sequences located in a montane area of Canterbury, New Zealand, I. Clay mineralogy and cation exchange properties. Geoderma 47: 261-282. Link: https://bit.ly/2Xw4JhW
49. Hem JD (1986) Study and interpretation of the chemical characteristics of natural water. U.S. Geological Survey Water-Supply Paper $22543^{\text {rd }}$ Ed. Scientific Pub. Jodhpur 263. Link: https://on.doi.gov/2MreilF

50. Hem JD (1991) Study and Interpretation of the Chemical Characteristics of Natural Waters. Scientific Publ Jodhpur India 2254, 263. Link: https://on.doi.gov/3eIXQPW

51. Chandra Sekhar M, Prasad S (2005) Regression model for assessment of dissolved pollutants in Krishna river. Journal of Indian Water Resources Society 25: 46- 49 .

52. Kwok-wing C (2006) A review on integration of artificial intelligence into water quality modelling. Marine Pollution Bulletin 52: 726-733. Link: https://bit.ly/2Az5pu3

53. Chebotarev II (1955) Metamorphism of natural waters in the crust of weathering. Parts 1-3. Geochim Cosmochim Acta 8: 22-32. Link: https://bit.ly/30cWeKB

54. Campbell MJ, Machin D (1993) Medical Statistics A Commonsense Approach. $2^{\text {nd }}$ Ed. Wiley, London.

55. Carroll D (1962) Rainwater as a chemical agent of geologic processes - a review. U.S Geological Survey water supply paper 520-f. 97-104. Link: https://on.doi.gov/304jNVK

56. Gupta AK, Patil RS, Gupta SK (2004) A statistical analysis of coastal wate quality for Jawaharlal Nehru Port and surrounding harbour region in India. International Journal of Environmental Monitoring and Assessment 95: 295 309. Link: https://bit.ly/2MrTMrh

57. Handa BK (1964) Modified classification procedure for rating irrigation water soil sci 98: 246-269. Link: https://bit.ly/2MqXUYu

58. Brown RM, McClelland NI, Deininger RA, Tozer RG (1970) A Water quality index - Do we dare?. Water and Sewage Works 339-343.

59. Hardgrave BC, Wilson RL, Walstrom KA (1994) Predicting graduate student success: A comparison of neural networks and traditional techniques. Computers and Operations Research 21: 249-263. Link: https://bit.ly/2XXWvyf

60. He C, Shi C, Yang C, Agosti BP (2001) A Windows-based GISAGNPS interface. Journal of the American Water Resources Association 37: 395-406. Link: https://bit.ly/306WR8r

\section{Discover a bigger Impact and Visibility of your article publication with}

\section{Peertechz Publications}

\section{Highlights}

* Signatory publisher of ORCID

* Signatory Publisher of DORA (San Francisco Declaration on Research Assessment)

* Articles archived in worlds' renowned service providers such as Portico, CNKI, AGRIS, TDNet, Base (Bielefeld University Library), CrossRef, Scilit, J-Gate etc.

* Journals indexed in ICMJE, SHERPA/ROMEO, Google Scholar etc.

* OAI-PMH (Open Archives Initiative Protocol for Metadata Harvesting)

* Dedicated Editorial Board for every journal

* Accurate and rapid peer-review process

* Increased citations of published articles through promotions

* Reduced timeline for article publication

Submit your articles and experience a new surge in publication services (https://www.peertechz.com/submission).

Peertechz journals wishes everlasting success in your every endeavours.

Copyright: (c) 2020 Chatterjee A, et al. This is an open-access article distributed under the terms of the Creative Commons Attribution License, which permits unrestricted use, distribution, and $r$ eproduction in any medium, provided the original author and source are credited.

Citation: Chatterjee A, Ganesh S (2020) Analysis of physicochemical parameters of the Hebbal, Shivpura, Elemallappa Shetty Lakes in Bengaluru City, India. Ann Limnol Oceanogr 5(1): 001-007. DOI: https://dx.doi.org/10.17352/alo.000009 